\title{
Correlations and Organisational Effects of Compensation and Benefits, Job Satisfaction, Career Satisfaction and Job Stress in Public and Private Hospitals in Lucknow, India
}

\author{
N Saxena and H Rai
}

\begin{abstract}
The present study compares the organisational effect of compensation and benefits in public and private hospitals. It was observed that private hospital employees were more satisfied with their compensation and benefits as compared to the employees of government hospitals. Furthermore, the employees who were satisfied with their compensation and benefits were also found to be satisfied with their jobs.
\end{abstract}

\section{Neha Saxena}

PhD Scholar

Uttar Pradesh Technical University

India.

\section{Himanshu Rai}

Dean - MISB Bocconi

Bocconi School of Management

Milan, Italy.

Correspondence:

himanshu@iiml.ac.in

\section{Introduction}

Societies and governments across the globe look upon healthcare as service first and industry second. The enormous growth in medical science due to technological advancements has given more power to professionals working in this sector to understand medical problems with greater efficacy and cost-effectiveness than ever before. Healthcare faces the ever present challenge of improving its productivity as well as cost-effectiveness through the development of its Human Resource (HR) capability. This is achieved by managing the expertise of professionals through education, research and training as well as maintaining their motivation through the availability of facilities, compensation and benefits, legal and organisational support, and constructing an environment conducive to relationships between clients from various areas.
Abbreviations: HR - Human Resources.

Key words: compensation and benefit, career satisfaction; job satisfaction; job stress; private hospitals; public hospitals.
The healthcare industry in India is flourishing with a doubledigit growth rate that is expected to continue into the future. This is concerning given that deficiencies like the lack of comprehensive infrastructure and poorly defined services in the regularisation of the private healthcare sector in Bangladesh after its rapid expansion has reportedly led to dissatisfaction from consumers. [14] For India to meet international standards and to provide cost-effective health solutions, proactive participation of the government and private sector is required.

Best HR practices are important to such places where training, motivating and retaining professionals is the backbone of their operation. With that consideration, the present study investigates healthcare professionals' perception of job satisfaction in view of their compensation and benefits and suggests recommendations with regard to career satisfaction and job stress.

\section{Literature review}

India does not score well in the area of healthcare services. In the state of Rajasthan, a case study of thirty small hospitals by Kumar et al [7] revealed a kind of casual approach to managing HR functions. At fifteen out of thirty hospitals, the physician or the owner was in charge of the governance activity without any conventional training in HR functions. In eight other hospitals, HR management was the duty of the non-medical spouse of the doctor entrepreneurs. Case 
leads in eighteen hospitals showed that they lacked a HR management/development specific activity. Fields such as the development and welfare of employees, performance estimation, workforce planning and so on were considered important but not handled in an organised manner. [7] Similar effects have been apparent from various studies conducted abroad, such as in Pakistan by Lalani [8] and the British healthcare sector by Bach [1] reflecting the vital importance of HR management practices.

$H R$ functions relate to HR outcomes in terms of patient care and the maintenance of hospital assets, profitability and productivity. Research in the healthcare industry has demonstrated that the proper distribution of compensation and benefits is of crucial importance. $[11,3]$

Competitive compensation and benefits for healthcare employees help to increase their motivation levels, which in turn improves functioning and impacts positively on the retention of a talented workforce. [11] The shortage of physicians, nurses and hospital administrators in the rural healthcare sector can be overcome by offering attractive pay packages. [18] A lucid and objective compensation and benefits system helps to improve the morale of employees and increase their public presentation through its proper management. [3]

Efficient HR practices result in job satisfaction and organisational commitment in employees. [19] Managers and hospital administrators should plan and implement effective health policies in order to meet the unique needs of their staff and organisations. [2] Job stress and poor career opportunities results in an increase in the rate of employee absenteeism. [17,9] An overall awareness about HR management is found to be lacking consistency and uniformity across the globe, especially in less developed countries.

To the best of our knowledge, there is no Indian study that compares compensation and benefits and their affect on job satisfaction, career satisfaction and job stress experienced by employees of private hospitals to that experienced by government hospital employees in the Indian health sector. Therefore, the present study has been undertaken to find out if there is any difference between compensation and benefits and their affect on the job satisfaction, career satisfaction and job stress among the employees of private and government hospitals.

\section{Research method}

\section{Sample and survey procedure}

The current study includes ten hospitals in the city of
Lucknow. Of these, five are government hospitals and the remaining five are private. In each of the hospitals the personnel to be interviewed were organised in three categories: a) Administrators b) Doctors c) Nurses. As far as possible in each of these sub-groups nearly equal numbers of personnel were included. They were interviewed on the basis of a closed standard questionnaire (having options based on a 5-point Likert scale). Out of 260 questionnaires 80 were allotted to the administrators, 90 to the doctors, and 90 to the nurses. Forty-five administrators responded to the instrument with a response rate of $56 \%, 81$ doctors with a response rate of $90 \%$ and 77 nurses with a response rate of 85\%. In total 203 employees were interviewed.

\section{Measures}

The survey instrument was chosen based on robust psychometric properties and the items used in the study were:

Compensation and Benefit scale (26 items), developed by Bergmann et al, 1999. The scale is taken from the paper 'The Pay Procedures: what makes them fair?' from the Journal of Occupational and Organisational Psychology. This measures the human psychology in an organisation related to compensation and benefits and is therefore appropriate for our study.

Job Satisfaction Scale (7 Items), developed by Bowers et al 1974. This measure is taken from the paper'The Experience of Work: a compendium of 249 measures and their use. London'. It is the most commonly used and reliable scale for determining the level of job satisfaction among the employees.

Career Satisfaction Scale (5 Items), developed by Greenhaus et al, 1990. This measure was taken from the paper 'The Effects of Race on Organisational Experiences, Job Performance Evaluation and Career Outcomes' from the Academy Of Management Journal. We have used this scale for our study as it measures the satisfaction with the career success and also assesses the extent to which an employee has made satisfactory progress towards goals for advancement, income level and development of his/her expertise.

Job Stress Scale (15 Items), developed by House et al, 1979. This scale was taken from the paper 'Occupational Stress and Health among Factory Workers' from the Journal of Health and Social Behavior. We found it appropriate since it measures the frequency with which employees are perturbed by stressful occurrences. It includes five subscales that assess the extent of occupational stress due to job responsibilities, quality concerns, role conflict, job vs. nonjob conflict and workload. 
Job Stress Scale was further subdivided into five major items which were:

(i) Responsibility pressure: illustrates the stress experienced by an employee in carrying out his/her or other's job responsibility, either because the work involves risk or the lack of assistance.

(ii) Quality concern: explains the level of stress due to jeopardisation in the quality of work because of more quantity or lack of standards reached.

(iii) Role conflict: the stress due to the lack of compatibility in fulfilling the different expectations of others.

(iv) Job vs. Non-Job conflict: the stress resulting from the conflict between work and family roles.

(v) Workload: the stress resulting from large amounts of work assigned to or expected from an employee in a specific period of time.

The Compensation and Benefits Scale was divided into the following four major items:

(i) Supervision Support: the support that an employee's supervisor provides in relation to the compensation and benefits received.

(ii) Accuracy: explains the correctness on the part of the supervisor while administering the compensation and benefits. (iii) Process control: explains the involvement of the employees in the process of calculation and distribution of compensation and benefits.

(iv) Justification: the justification given to the employees to clarify their queries related to the calculation and distribution of their compensation and benefits.

\section{Results}

All variables were coded, computed and the data was analysed using various statistical measures such as regression, correlational statistics and ANOVA.

The summary of the analysis of the demographic variables has been depicted in Table 1.

Table 1 indicates that there were $84.4 \%$ married employees in public hospitals and 59\% in private hospitals. An agewise distribution of employees in various hospitals shows that more employees of government hospital fall in the age group of 30-40 years while in the private hospitals, more employees were in the age group of 20-30 years. The results indicated that on an average, private hospital employees were younger as compared to those of government hospitals. Table 1 also indicates that males outnumbered females both in the government hospitals as well as in private hospitals. Qualification-wise distribution shows that the maximum number of individuals who filled up the

Table 1: Summary of the analysis of demographic variables

\begin{tabular}{|l|c|c|c|c|c|}
\hline MARITAL STATUS & $\begin{array}{c}\text { PUBLIC } \\
\text { HOSPITALS }\end{array}$ & $\%$ & $\begin{array}{c}\text { PRIVATE } \\
\text { HOSPITALS }\end{array}$ & $\begin{array}{c}\text { TOTAL } \\
\text { EMPLOYEES }\end{array}$ \\
\hline Unmarried & 16 & 15.53 & 41 & 41 & 57 \\
Married & 87 & 84.46 & 59 & 59 & 146 \\
\hline AGE IN YEARS & & & & & \\
20-30 & 20 & 19.41 & 55 & 55 & 75 \\
$30-40$ & 29 & 28.15 & 23 & 23 & 52 \\
$40-50$ & 26 & 25.24 & 11 & 11 & 37 \\
50-60 & 27 & 26.21 & 4 & 4 & 31 \\
60-70 & 1 & 0.97 & 7 & 7 & 8 \\
$70-80$ & 0 & 0 & 0 & 0 & 0 \\
\hline SEX & & & & & \\
Male & 57 & 55.35 & 55 & 55 & 112 \\
Female & 46 & 44.66 & 45 & 45 & 91 \\
\hline HIGHEST EDUCATIONAL QUALIFICATION & & & & & \\
Diploma & 21 & 20.38 & 25 & 25 & 46 \\
Graduation & 22 & 21.35 & 26 & 26 & 48 \\
Masters & 55 & 53.39 & 44 & 44 & 99 \\
\hline
\end{tabular}


questionnaire belonged to a higher qualification category: Masters degrees such as MD, MS, MA, M.Sc. etc; followed by graduates (that is Medical Graduates, Bachelors of Science or Arts etc.) and diploma holders (General Nursing, Midwifery (G.N.M), etc.) and then higher degree holders such as PhD, M.Ch.etc.

The results shown in Table 2 indicate that all the scales and subscales are reliable.
Similarly, Table 4b shows a significant and positive relationship between compensation and benefits and career satisfaction $(p=0.0001)$. Employees who were satisfied with their compensation and benefits were also found to be satisfied with their career. Among the components of compensation and benefits process control items $(p=0.006)$ and the justification items $(p=0.053)$ were found to be significantly and positively related to job satisfaction as shown in Table 4c.

Table 2: Chronbach's alpha value of various scales and subscales

\begin{tabular}{|c|c|c|c|c|c|c|c|c|c|c|c|c|}
\hline VARIABLES & $\begin{array}{c}\text { JOB } \\
\text { SATISFACTION }\end{array}$ & $\begin{array}{c}\text { CAREER } \\
\text { SATISFACTION }\end{array}$ & $\begin{array}{c}\text { JOB } \\
\text { STRESS }\end{array}$ & $\begin{array}{c}\text { JOB STRESS } \\
\text { (RESPONSIBILITY } \\
\text { PRESSURE ITEM) }\end{array}$ & $\begin{array}{c}\text { JOB STRESS } \\
\text { (QUALITY } \\
\text { CONCERN ITEM) }\end{array}$ & $\begin{array}{c}\text { JOB STRESS } \\
\text { (ROLE CONFLICT } \\
\text { ITEM) }\end{array}$ & $\begin{array}{l}\text { JOB STRESS } \\
\text { (JOB VS NON- } \\
\text { ITEM) }\end{array}$ & $\begin{array}{c}\text { JOB STRESS } \\
\text { (WORKLOAD } \\
\text { ITEM) }\end{array}$ & $\begin{array}{l}\text { COMPENSATION } \\
\text { AND BENEFITS }\end{array}$ & \begin{tabular}{|c|} 
COMPENSATION \\
AND BENEFITS \\
(SUPERVISION \\
SUPPORT \\
ITEMS)
\end{tabular} & $\begin{array}{c}\text { COMPENSATION } \\
\text { AND BENEFITS } \\
\text { (ACCURACY } \\
\text { ITEMS) }\end{array}$ & $\begin{array}{l}\text { COMPENSATION } \\
\text { AND BENEFITS } \\
\text { (PROCESS } \\
\text { CONTROL) }\end{array}$ \\
\hline $\begin{array}{l}\text { Chronbach's } \\
\text { alpha }\end{array}$ & 0.8 & 0.81 & 0.85 & 0.64 & 0.68 & 0.62 & 0.68 & 0.82 & 0.96 & 0.92 & 0.94 & 0.96 \\
\hline
\end{tabular}

Table 3: Correlation values of Job Satisfaction, Career Satisfaction, Job Stress and Compensation and Benefits

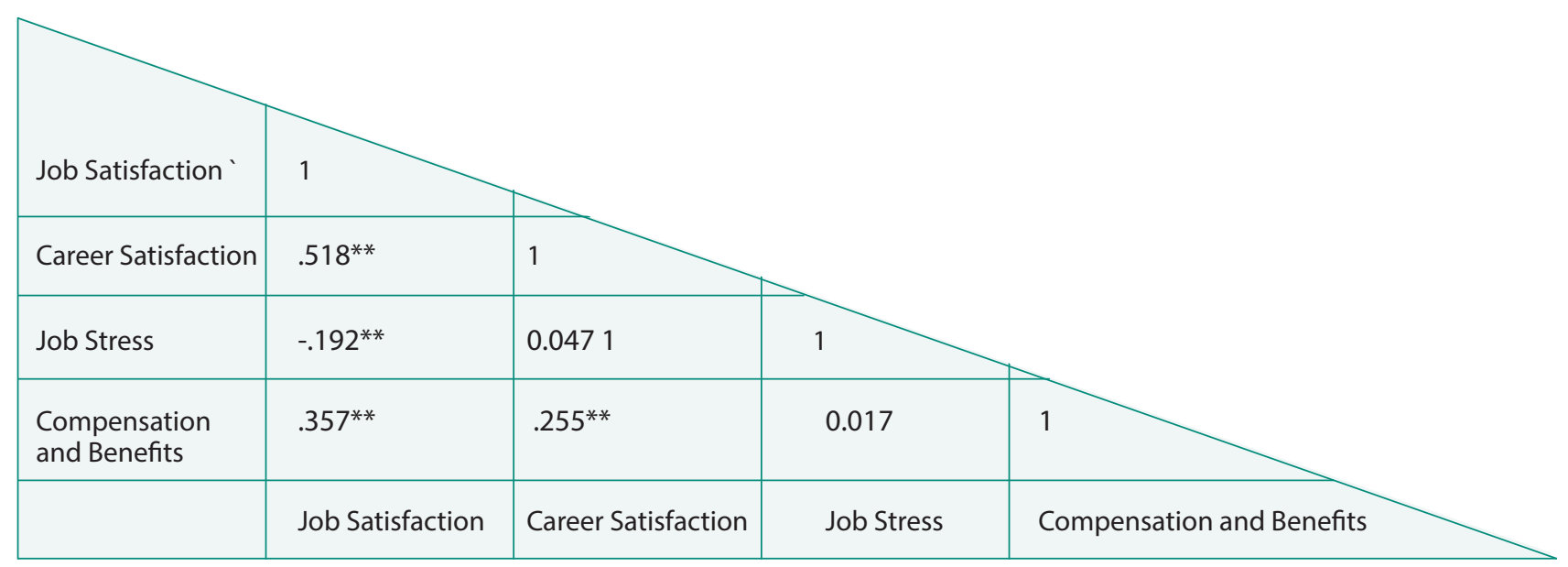

As shown in Table 3, compensation and benefits have been found to be correlated with job satisfaction and career satisfaction, yet no correlation was observed with job stress. The employees who were satisfied with their compensation and benefits were also found to be satisfied with their job $(r=0.36)$ and career $(r=0.26)$.

As per the results of regression analysis as shown in Table $4 \mathrm{a}$, the independent variable compensation and benefits was found to be positively and significantly related to the dependent variable job satisfaction $(p=0.0001)$. Employees who were satisfied with their compensation and benefits were also found to be satisfied with their jobs.
This shows that higher the involvement of the employee in the process of calculation and distribution of compensation and benefits, the more likely he/she was to be satisfied with his/her job. If an organisation follows a transparent system of providing compensation and benefits to the employees, by forwarding legitimate justifications regarding queries on the calculation and distribution of the same, it is seen to result in employees being satisfied with their jobs. Analysis of job stress with compensation and benefits using regression revealed no significant relationship between the two parameters. 
Table 4a: Regression result of compensation and benefits, and job satisfaction

\begin{tabular}{|l|c|c|c|c|}
\hline MODEL SUMMARY & $\mathrm{R}$ & R SQUARE & ADJUSTED R SQUARE & $\begin{array}{c}\text { STD. ERROR OF THE } \\
\text { ESTIMATE }\end{array}$ \\
\hline MODEL & $.357^{\mathrm{a}}$ & 0.127 & 0.123 & 0.60667 \\
\hline 1 & & & \\
\hline
\end{tabular}

a. Predictors: (Constant), Compensation and Benefits

\begin{tabular}{|c|c|c|c|c|c|c|}
\hline \multicolumn{7}{|c|}{ COEFFICIENTS $^{\mathrm{a}}$} \\
\hline \multirow[t]{2}{*}{ MODEL } & \multicolumn{3}{|c|}{ UNSTANDARDIZED COEFFICIENTS } & \multirow{2}{*}{$\begin{array}{c}\text { STANDARDIZED } \\
\text { COEFFICIENTS }\end{array}$} & \multirow[t]{2}{*}{$\mathbf{T}$} & \multirow[t]{2}{*}{ SIG. } \\
\hline & & & STD. ERROR & & & \\
\hline \multirow[t]{2}{*}{1} & (Constant) & 2.881 & 0.171 & & 16.864 & 0.0001 \\
\hline & $\begin{array}{c}\text { Compensation } \\
\text { and Benefits }\end{array}$ & 0.29 & 0.054 & 0.357 & 5.417 & 0.0001 \\
\hline
\end{tabular}

a. Dependent Variable: Job Satisfaction

Table 4b: Regression result of compensation and benefits and career satisfaction

\begin{tabular}{|c|c|c|c|c|}
\hline \multicolumn{5}{|c|}{ MODEL SUMMARY } \\
\hline MODEL & $\mathbf{R}$ & R SQUARE & ADJUSTED R SQUARE & $\begin{array}{l}\text { STD. ERROR OF THE } \\
\text { ESTIMATE }\end{array}$ \\
\hline 1 & $.235^{\mathrm{a}}$ & 0.065 & 0.6 & 0.77715 \\
\hline
\end{tabular}

a. Predictors: (Constant), Compensation and Benefits

\begin{tabular}{|c|c|c|c|c|c|c|}
\hline \multicolumn{7}{|c|}{ COEFFICIENTS } \\
\hline \multirow[t]{2}{*}{ MODEL } & \multicolumn{3}{|c|}{ UNSTANDARDIZED COEFFICIENTS } & \multirow{2}{*}{$\begin{array}{c}\text { STANDARDIZED } \\
\text { COEFFICIENTS } \\
\text { BETA }\end{array}$} & \multirow[t]{2}{*}{$\mathrm{T}$} & \multirow[t]{2}{*}{ SIG. } \\
\hline & & & STD. ERROR & & & \\
\hline \multirow[t]{2}{*}{1} & (Constant) & 2.79 & 0.219 & & 12.748 & 0.0001 \\
\hline & $\begin{array}{l}\text { Compensation } \\
\text { and Benefits }\end{array}$ & 0.256 & 0.069 & 0.255 & 3.732 & 0.0001 \\
\hline
\end{tabular}

a. Dependent Variable: Career Satisfaction

Table 4c: Regression results of supervision support, accuracy, process control and justification items of compensation and benefits and job satisfaction

\begin{tabular}{|l|c|c|c|c|}
\hline \multicolumn{5}{|l|}{ MODEL SUMMARY } \\
\hline MODEL & $\mathrm{R}$ & R SQUARE & ADJUSTED R SQUARE & $\begin{array}{c}\text { STD. ERROR OF THE } \\
\text { ESTIMATE }\end{array}$ \\
\hline 1 & $.368^{\mathrm{a}}$ & 0.136 & 0.118 & 0.60837 \\
\hline
\end{tabular}

a. Predictors: (Constant), compensation and benefits (justification item), Compensation and benefits (process control item), Compensation and benefits (accuracy item), Compensation and benefits (supervision support item) 
Correlations and Organisational Effects of Compensation and Benefits, Job Satisfaction, Career Satisfaction and Job Stress in Public and Private Hospitals in Lucknow, India

Table 4c: Regression results of supervision support, accuracy, process control and justification items of compensation and benefits and job satisfaction continued

\begin{tabular}{|c|c|c|c|c|c|c|}
\hline \multicolumn{7}{|c|}{ COEFFICIENTS } \\
\hline \multirow{2}{*}{\multicolumn{2}{|c|}{ MODEL }} & \multicolumn{2}{|c|}{$\begin{array}{l}\text { UNSTANDARDIZED } \\
\text { COEFFICIENTS }\end{array}$} & \multirow{2}{*}{$\begin{array}{c}\text { STANDARDIZED } \\
\text { COEFFICIENTS } \\
\text { BETA } \\
\end{array}$} & \multirow[t]{2}{*}{$\mathrm{T}$} & \multirow[t]{2}{*}{ SIG. } \\
\hline & & B & STD. ERROR & & & \\
\hline \multirow[t]{5}{*}{1} & (Constant) & 2.895 & 0.174 & & 16.623 & 0.0001 \\
\hline & $\begin{array}{l}\text { Compensation } \\
\text { and (supervision } \\
\text { support item) }\end{array}$ & 0.032 & 0.076 & 0.046 & 0.414 & 0.679 \\
\hline & $\begin{array}{l}\text { Compensation } \\
\text { and benefits } \\
\text { (accuracy item) }\end{array}$ & 0.036 & 0.078 & 0.05 & 0.464 & 0.643 \\
\hline & $\begin{array}{l}\text { Compensation } \\
\text { and benefits } \\
\text { (process control } \\
\text { item) }\end{array}$ & 0.126 & 0.046 & 0.213 & 2.761 & 0.006 \\
\hline & $\begin{array}{c}\text { Compensation } \\
\text { and benefits } \\
\text { (justification item) }\end{array}$ & 0.095 & 0.049 & 0.158 & 1.948 & 0.053 \\
\hline
\end{tabular}

a. Dependent Variable: Job Satisfaction

Analysis of the data by ANOVA produced the following results:

Table 5a shows one way ANOVA result of compensation and benefits by the type of hospital. It reveals that the compensation and benefits differed significantly between public and private.

As illustrated in the Table $5 \mathrm{~b}$, job satisfaction level differed significantly between males and females $(p=0.008)$.

As shown in Table 6a the type of hospital was significantly and positively related to job satisfaction. Private hospital employees were found to be more satisfied with their jobs as compared to those of government hospitals ( $p=0.02$ ).

As shown in regression Table $6 b$, when the sex of the personnel was related to job satisfaction, it was observed that males were more satisfied with their jobs as compared to females $(p=0.13)$. According to the data collected, $66 \%$ of

Table 5a: One way ANOVA result of compensation and benefits by the type of hospitals

\begin{tabular}{|l|l|c|c|c|c|c|}
\hline \multicolumn{2}{|c|}{} & $\begin{array}{c}\text { SUM OF } \\
\text { SQUARES }\end{array}$ & DF & $\begin{array}{c}\text { MEAN } \\
\text { SQUARE }\end{array}$ & SIG \\
\hline $\begin{array}{l}\text { Compensation } \\
\text { and Benefits }\end{array}$ & $\begin{array}{l}\text { Between } \\
\text { Groups }\end{array}$ & 12.6131 & 1 & 2.613 & 21.967 & 0.0001 \\
\cline { 2 - 7 } & $\begin{array}{l}\text { Within } \\
\text { Groups }\end{array}$ & 115.414 & 201 & .574 & & \\
\cline { 2 - 8 } & Total & 128.027 & 202 & & & \\
\hline
\end{tabular}

Table 5b: One way ANOVA result of job satisfaction by sex of the employee

\begin{tabular}{|l|l|c|c|c|c|c|}
\hline \multicolumn{2}{|c|}{} & $\begin{array}{c}\text { SUM OF } \\
\text { SQUARES }\end{array}$ & DF & $\begin{array}{c}\text { MEAN } \\
\text { SQUARE }\end{array}$ & F & SIG \\
\hline \multirow{2}{*}{$\begin{array}{l}\text { Job } \\
\text { Satisfaction }\end{array}$} & $\begin{array}{l}\text { Between } \\
\text { Groups }\end{array}$ & 2.892 & 1 & 2.892 & 7.098 & 0.008 \\
\cline { 2 - 7 } & $\begin{array}{l}\text { Within } \\
\text { Groups }\end{array}$ & 81.886 & 201 & 0.407 & & \\
\cline { 2 - 7 } & Total & $\mathbf{8 4 . 7 7 8}$ & $\mathbf{2 0 2}$ & & & \\
\hline
\end{tabular}


the females were married and about $49 \%$ were above the age of 30 . The score of job satisfaction for females was found to be low. Also, it illustrates the same results as given in Table $6 a$, above, that private hospital employees were found to be more satisfied with the compensation and benefits than those of government hospitals $(p=0.0001)$.

\section{Discussion}

The present study was undertaken to compare the effect of compensation and benefits on job satisfaction, career satisfaction and job stress. The application of HR management practices in the healthcare industry is a relatively new concept of the current century. To-date there have been some superficial attempts to incorporate HR

Table 6a: Regression result of type of hospital, marital status, age, sex, highest educational qualification, total work experience, experience in the current job and job satisfaction

\begin{tabular}{|c|c|c|c|c|}
\hline \multicolumn{5}{|c|}{ MODEL SUMMARY } \\
\hline MODEL & $\mathbf{R}$ & R SQUARE & ADJUSTED R SQUARE & $\begin{array}{l}\text { STD. ERROR OF THE } \\
\text { ESTIMATE }\end{array}$ \\
\hline 1 & $.276^{\mathrm{a}}$ & 0.076 & 0.043 & 0.63383 \\
\hline
\end{tabular}

a. Predictors: (Constant), Experience in the Current Job, Sex, Marital Status, Type of Hospital, Highest Educational Qualification, Total Work Experience, Age

\begin{tabular}{|c|c|c|c|c|c|c|}
\hline \multicolumn{7}{|c|}{ COEFFICIENTS ${ }^{a}$} \\
\hline \multirow{2}{*}{\multicolumn{2}{|c|}{ MODEL }} & \multicolumn{2}{|c|}{ UNSTANDARDIZED COEFFICIENTS } & \multirow{2}{*}{$\begin{array}{c}\text { STANDARDIZED } \\
\text { COEFFICIENTS }\end{array}$} & \multirow[t]{2}{*}{$\mathrm{T}$} & \multirow[t]{2}{*}{ SIG. } \\
\hline & & B & STD. ERROR & & & \\
\hline \multirow[t]{8}{*}{1} & (Constant) & 3.372 & 0.178 & & 18.931 & 0.0001 \\
\hline & Type of Hospital & 0.232 & 0.099 & 0.179 & 2.346 & 0.02 \\
\hline & Marital Status & -0.024 & 0.119 & -0.017 & -0.201 & 0.841 \\
\hline & Age & 0.133 & 0.089 & 0.25 & 1.492 & 0.137 \\
\hline & Sex & 0.251 & 0.1 & 0.193 & 2.505 & 0.013 \\
\hline & $\begin{array}{l}\text { Highest } \\
\text { Educational } \\
\text { Qualification }\end{array}$ & -0.018 & 0.06 & -0.025 & -0.306 & 0.76 \\
\hline & $\begin{array}{l}\text { Total Work } \\
\text { Experience }\end{array}$ & -0.001 & 0.001 & -0.228 & -1.399 & 0.163 \\
\hline & $\begin{array}{l}\text { Experience in } \\
\text { the Current Job }\end{array}$ & 0.001 & 0.001 & 0.151 & 1.664 & 0.098 \\
\hline
\end{tabular}

a. Dependent Variable: Career Satisfaction

Table 6b: Regression result of type of hospital, marital status, age, sex, highest educational qualification, total work experience, experience in the current job and compensation and benefits

\begin{tabular}{|l|c|c|c|c|}
\hline MODEL SUMMARY & $\mathrm{R}$ & R SQUARE & ADJUSTED R SQUARE & $\begin{array}{c}\text { STD. ERROR OF THE } \\
\text { ESTIMATE }\end{array}$ \\
\hline MODEL & $.359^{\mathrm{a}}$ & 0.129 & 0.097 & 0.75641 \\
\hline 1 & & & & 0.7567 \\
\hline
\end{tabular}

a. Predictors: (Constant), Experience in the Current Job, Sex, Marital Status, Type of Hospital, Highest Educational Qualification, Total Work Experience, Age 
Correlations and Organisational Effects of Compensation and Benefits, Job Satisfaction, Career Satisfaction and Job Stress in Public and Private Hospitals in Lucknow, India

Table 6b: Regression result of type of hospital, marital status, age, sex, highest educational qualification, total work experience, experience in the current job and compensation and benefits continued

\begin{tabular}{|c|c|c|c|c|c|c|}
\hline \multicolumn{7}{|c|}{ COEFFICIENTS ${ }^{a}$} \\
\hline \multirow{2}{*}{\multicolumn{2}{|c|}{ MODEL }} & \multicolumn{2}{|c|}{ UNSTANDARDIZED COEFFICIENTS } & \multirow{2}{*}{$\begin{array}{c}\text { STANDARDIZED } \\
\text { COEFFICIENTS } \\
\text { BETA }\end{array}$} & \multirow[t]{2}{*}{$\mathbf{T}$} & \multirow[t]{2}{*}{ SIG. } \\
\hline & & B & STD. ERROR & & & \\
\hline \multirow[t]{8}{*}{1} & (Constant) & 2.865 & 0.213 & & 3.479 & 0.0001 \\
\hline & Type of Hospital & 0.537 & 0.118 & 0.338 & 4.562 & 0.0001 \\
\hline & Marital Status & -0.166 & 0.141 & -0.094 & -1.17 & 0.243 \\
\hline & Age & 0.088 & 0.107 & 0.134 & 0.824 & 0.411 \\
\hline & Sex & -0.107 & 0.12 & -0.067 & -0.898 & 0.37 \\
\hline & $\begin{array}{l}\text { Highest } \\
\text { Educational } \\
\text { Qualification }\end{array}$ & -0.042 & 0.072 & -0.047 & -0.59 & 0.556 \\
\hline & $\begin{array}{l}\text { Total Work } \\
\text { Experience }\end{array}$ & 0 & 0.001 & 0.039 & 0.243 & 0.808 \\
\hline & $\begin{array}{l}\text { Experience in } \\
\text { the Current Job }\end{array}$ & $7.80 \mathrm{E}-05$ & 0.001 & 0.009 & 0.105 & 0.917 \\
\hline
\end{tabular}

a. Dependent Variable: Compensation and Benefits

practices into this sector as found in studies done in various countries: for example, in India by Kumar et al, [7] Pakistan by Lalani [8] as well as in western countries like the United Kingdom by Bach [1] and the United States by Long. [10] However, it has been emphasised that efficient HR practices are crucial for improving the quality of healthcare. In the present study, it was observed that none of the government hospitals had an HR department to look after the interests of their employees. Instead, the directors or medical superintendents were looking after HR practices, while they did not have an adequate knowledge about HR management. All these people were basically doctors who were busy treating their patients and additionally loaded with other clinical work. These personnel have hardly any time to look after the tasks of HR management. Similar observations have also been made by Kumar et al [7] and Lalani. [8] In our survey, $80 \%$ of the private hospitals had an HR department/section responsible for the recruitment, selection, preparation, performance assessment, along with managing the compensation and benefits of personnel. We observed higher levels of job and career satisfaction in private hospital employees due to greater satisfaction with the compensation and benefits by private hospital employees as compared to government hospital employees. Among the items of compensation and benefits, process control item and the justification item had the most significant impact on job satisfaction. In the present study, a greater number of younger people with less work experience were found to be employed in private hospitals as compared to government hospitals, probably due to stringent recruitment and selection processes followed by government hospitals.

A fair and transparent process of calculation and distribution of compensation and benefits would likely result in greater job satisfaction, career satisfaction, and hence, lower levels of job stress for employees.

The present study also found that the male respondents were more gratified with their jobs than were female respondents. This may be due to the prevalent patriarchal system in Indian society that bestows certain advantages, status and privileges on the male at the expense of females. Nevertheless, it is a mark of enormous social progress that more and more women are receiving better training and are being developed to undertake professional duties. And yet, frequently enough, women engaged in professional work still have to fulfill household duties without getting much or any contribution from their spouse. As a result of this, they are often overworked which contributes to lower levels of job satisfaction while their male counterparts usually assume major roles in the workplace. This has also been reported by Khuwaja et al [6] in Pakistan, Kaptanoglu et al [5] and Ronald et al [16] in Turkey and Patrick et al [13] in Russia, where female physicians tend to be absent more 
frequently and reported more psychosomatic problems and work-family conflict than their male counterparts due to time constraints posed by their hospital duties. Additionally, female workers, especially the nursing staff which is largely comprised of women, are more prone to physical assaults. [16]

The present study has some limitations. A larger sample size could possibly make the study more robust. Thus the study needs to be extended to a larger number of hospitals in the country in order to reach a definite conclusion as to how compensation and benefits impact the performance of hospitals, both private and public. Other HR practices could also be included in future studies to analyse their effect on the job satisfaction, career satisfaction, and job stress experienced by the employees of an organisation.

\section{Conclusion}

The study builds on a body of work that stresses on the importance of HR functions as the key contributors to the performance and growth of organisations, particularly healthcare. Effective HR management means recruiting and selecting a suitable workforce, ensuring that employees are adequately trained and that work is appropriately assigned, while also keeping them motivated through the process of proper incentivising, compensation and benefits, among other things.

Compensation and various types of benefits which include disability income protection, retirement benefits, sick leave, vacation (paid and non-paid), daycare, funds for education, as well as flexible and alternative work arrangements help to retain a more qualified workforce in the healthcare sector. Regular meetings should be held between staff and management to work out solutions to problems. A culture of work-life balance should be introduced in hospitals, which may include the development of some facilities such as day care, paid leave (paternity, maternity and parental leave, leave for the care of young children, leave for the care of a sick child) etc, especially aimed at maintaining female employee satisfaction. Organisations should also offer ample opportunities for the career development of hospital employees and must provide them greater autonomy and allow them to be a part of the decision-making committees, including compensation and benefits, as it has also been observed that employees face stress mostly when they are not involved in the decisions taken that are closely related to themselves and their work.

\section{Acknowledgement}

We take this opportunity to express our gratitude to the members of our Institute, Indian Institute of Management, Lucknow and U.P.T.U. for their support.

\section{Competing interests}

The authors declare they have no competing interests.

\section{References}

1. Bach S. HR and new approaches to public sector management improving HRM capacity (accessed June 11, 2011). Geneva: World Health Organisation, Department of Organisation of Health Services Delivery; 2000. Available from: <http://www.who.int/hrh/ en/Improving_hrm_capacity/download/pages/1-43.pdf>

2. Baghaei R. A comparative study of Human Resource Management practices in private and public hospitals of Iran with special reference to job satisfaction of nurses (accessed Feb 2, 2012). 2009. Available from: $<$ http://shodhganga.inflibnet.ac.in/ bitstream/ 10603/2009/7/07_abstract/download/pages/1.pdf.>

3. Carroll M, Cox A, Grimshaw D, McBride A. Reshaping internal labor markets in the National Health Service: new prospects for pay and training for lower skilled service workers? Hum Resour Manag J. 2008;18(4):347-365.

4. Jordan S, Snelgrove K. Transition from hospital to home development of a settling service for the Emergency Department and the Acute Assessment Unit. Asia Pac J Health Manag. 2011; 6(2):51-56.

5. Kaptanoglu AY, Demir T. Examining job satisfaction among perfusionists: a brief report from Istanbul. J Pakistan Med Asso. 2013;63(9):1157-1162.

6. Khuwaja AK, Qureshi R, Andrades M, Fatmi Z, Khuwaja NK. Comparison of job satisfaction and stress among male and female doctors in teaching hospitals of Karachi. J Ayub Med Coll Abbottabad. 2004;16(1):23-70.

7. Kumar S, Yadav MPS, Chowdhary N. Organizing human resource management function in small hospitals. Pranjana. 2010; 13(2):16-26.

8. Lalani F. Effective utilization of human resource management: a comparative study of public and private hospitals in Sindh, Pakistan (accessed June 5, 2011). Research Repository 2007. Available from:<http://eprints.hec.gov.pk/2671/1/2517.htm/ download/ pages/1-335.pdf.>

9. Lee JSY, Akhtar S. Job burnout among nurses in Hong Kong: Implications for human resource practices and interventions. Asia Pac J Hum Resour. 2007;45(1):63-84.

10. Long JE. Grounded Theory: its use in recruitment and retention. J Manag Mark Res. 2006;11(1):1-8.

11. Myers VL, Dreachslin JL. Recruitment and retention of a diverse workforce: challenges and opportunities. J Healthcare Manag. 2007;52(5):290-298.

12. O'Rourke M.The Australian Commission on Safety and Quality in Healthcare agenda for improvement and implementation. Asia Pac J Health Manag. 2007; 2(2):21-25.

13. Patrick OL, Natalia W, Thomas Q. Job satisfaction of physicians in Russia. Int J Healthcare Qual Assur. 2009; 2(3):221-231.

14. Rahman MR, Barraclough S. Regulation in the doldrums: reforming private healthcare sector legislation in Bangladesh. Asia Pac J Health Manag. 2006;1(2):22-28.

15. Rodriguez-Acosta RL, Myers DJ, Richardson DB, Lipscomb HJ, Chen JC, Dement JM. Physical assault among nursing staff employed in acute care. Work. 2010;35(2):191-200. 
16. Ronald B, Mustafa K, Lisa F. Gender differences in work experiences, satisfactions and wellbeing among physicians in Turkey. Gender Manag: Int J. 2009;24(2):70-91.

17. Shahzad K, Hayat K, Abbas, Bashir S, Rehman K. Antecedents of turnover and absenteeism: evidence from public sector institutions of Pakistan. Interdiscipl J Contemp Res Bus. 2011; 2(9):108-120.

18. Stretton DV, Douglas SB. Hosp Top: Res Perspect Healthcare. 2009;87(1):10-14.

19. West $M$, et al. Reducing patient mortality in hospitals: the role of human resource management. J Organ Behav. 2006;27(7): 983-1002. 